\title{
Multiple system atrophy: genetic risks and alpha-synuclein
}

\section{mutations [version 1; peer review: 2 approved]}

\section{Heather T Whittaker ${ }^{1}$, Yichen Qui², Conceição Bettencourt ${ }^{1,2}$, Henry Houlden (iD) 1,3,4}

\footnotetext{
${ }^{1}$ Department of Molecular Neuroscience, UCL Institute of Neurology, London, UK

${ }^{2}$ Department of Clinical and Experimental Epilepsy, UCL Institute of Neurology, London, UK

${ }^{3}$ MRC Centre for Neuromuscular Diseases, UCL Institute of Neurology, London, UK

${ }^{4}$ Neurogenetics Laboratory, The National Hospital for Neurology and Neurosurgery, London, UK
}

V1 First published: 30 Nov 2017, 6(F1000 Faculty Rev):2072

https://doi.org/10.12688/f1000research.12193.1

Latest published: 30 Nov 2017, 6(F1000 Faculty Rev):2072

https://doi.org/10.12688/f1000research.12193.1

\section{Abstract}

Multiple system atrophy (MSA) is one of the few neurodegenerative disorders where we have a significant understanding of the clinical and pathological manifestations but where the aetiology remains almost completely unknown. Research to overcome this hurdle is gaining momentum through international research collaboration and a series of genetic and molecular discoveries in the last few years, which have advanced our knowledge of this rare synucleinopathy. In MSA, the discovery of a-synuclein pathology and glial cytoplasmic inclusions remain the most significant findings. Families with certain types of a-synuclein mutations develop diseases that mimic MSA, and the spectrum of clinical and pathological features in these families suggests a spectrum of severity, from late-onset Parkinson's disease to MSA. Nonetheless, controversies persist, such as the role of common a-synuclein variants in MSA and whether this disorder shares a common mechanism of spreading pathology with other protein misfolding neurodegenerative diseases. Here, we review these issues, specifically focusing on a-synuclein mutations.

\section{Keywords}

multiple system atrophy, MSA, neurodegenerative disorders, asynuclein

\section{Open Peer Review}

Approval Status

1

2

version 1

30 Nov 2017

Faculty Reviews are review articles written by the prestigious Members of Faculty Opinions. The articles are commissioned and peer reviewed before publication to ensure that the final, published version is comprehensive and accessible. The reviewers who approved the final version are listed with their names and affiliations.

1. Mathias Toft, Oslo University Hospital, Oslo, Norway

2. Dean Pountney, Griffith University,

Queensland, Australia

Any comments on the article can be found at the end of the article. 
Corresponding author: Henry Houlden (h.houlden@ucl.ac.uk)

Author roles: Whittaker HT: Writing - Original Draft Preparation; Qui Y: Writing - Original Draft Preparation; Bettencourt C: Writing Original Draft Preparation; Houlden H: Conceptualization, Project Administration, Supervision, Writing - Review \& Editing

Competing interests: No competing interests were disclosed.

Grant information: We are grateful to the MSA Trust, the MSA Coalition (HH-MSA Coalition), the Medical Research Council (MRC UK) (HH-MRC), the Wellcome Trust (HH-WT)—equipment and the Synaptopathies Strategic Award (104033)—and the EU FP7/2007-2013 under grant agreement 2012-305121 (NEUROMICS), the MDA USA, Muscular Dystrophy UK, the Rosetrees Trust, Ataxia UK, and the Brain Research Trust. We are also supported by the National Institute for Health Research (NIHR) University College London Hospitals (UCLH) Biomedical Research Centre.

The funders had no role in study design, data collection and analysis, decision to publish, or preparation of the manuscript.

Copyright: ( 2017 Whittaker HT et al. This is an open access article distributed under the terms of the Creative Commons Attribution License, which permits unrestricted use, distribution, and reproduction in any medium, provided the original work is properly cited. Data associated with the article are available under the terms of the Creative Commons Zero "No rights reserved" data waiver (CC0 1.0 Public domain dedication).

How to cite this article: Whittaker HT, Qui Y, Bettencourt C and Houlden H. Multiple system atrophy: genetic risks and alphasynuclein mutations [version 1; peer review: 2 approved] F1000Research 2017, 6(F1000 Faculty Rev):2072

https://doi.org/10.12688/f1000research.12193.1

First published: 30 Nov 2017, 6(F1000 Faculty Rev):2072 https://doi.org/10.12688/f1000research.12193.1 


\section{Introduction}

Multiple system atrophy (MSA) is a neurodegenerative movement disorder affecting around 1 in 20,000 people $^{1,2}$. It occurs sporadically, usually presenting between the age of 35 and 65 years with a variable combination of parkinsonian, cerebellar, and autonomic features and rapidly progressing for 9 years on average $\mathrm{e}^{3-6}$. According to the presenting clinical features and predominant manifestations, MSA is usually categorised as MSA-C or MSA-P, there can be mixed signs, and some patients present with autonomic features. Familial MSA has been reported but in only a handful of cases worldwide. Research toward potential treatments for MSA, as with many rare diseases, has been limited, resulting in a paucity of knowledge regarding its underlying causes. Initial clues came from studying $\alpha$-synuclein (SNCA) and the hallmark histopathology in the brains of patients with MSA: glial cytoplasmic inclusions (GCIs) that reside predominantly in oligodendrocytes, the post mortem identification of which is required for a definitive diagnosis. Besides MSA, the only conditions that have GCIs in the brain are certain families with SNCA mutations. Three groups found that the GCIs contain abnormal forms of SNCA protein ${ }^{7-12}$, the same protein that accumulates in Parkinson's disease (PD) and dementia with Lewy bodies ${ }^{12}$. These studies were motivated by a link between point mutations in the $S N C A$ gene and heritable forms of $\mathrm{PD}^{13,14}$. The similarities between MSA and PD have proven more complicated to disentangle, as SNCA mutations in some families clinically and pathologically resemble MSA and others even have features of frontal dementia with severe pathology ${ }^{15}$.

It has been nearly two decades since MSA was characterised as a synucleinopathy, and apart from the PD-MSA overlap identified in SNCA families, researchers have not been able to further understand the aetiology of MSA or alter or halt the disease process. This brief review will set out the progress that has been made in recent years toward understanding the pathomechanisms of SNCA aggregation and toxicity in relation to MSA, particularly the emerging hypotheses of aetiology based on genetic studies. As clinical trials targeting SNCA proceed in PD and MSA, there is increasing urgency to better understand its relevant cellular interactions in parallel with the development of sensitive biomarkers capable of diagnosing patients at an earlier disease stage.

\section{The role of $\alpha$-synuclein in multiple system atrophy}

Despite the key involvement of abnormal SNCA processing, misfolding, and aggregation in synucleinopathies, the normal function of the protein is not fully understood. It is a peripheral membrane protein, localized at nerve terminals where it is thought to play a role in the release of neurotransmitters, and recently has been reported to enhance transient synaptic vesicle fusion ${ }^{16,17}$ and possibly disrupt the support and maintenance of neurons provided by oligodendrocytes. In MSA, SNCA is deposited widely, but there are more severely affected regions such as the basal ganglia, cerebellum, pons, inferior olivary nuclei, and spinal cord ${ }^{18,19}$. Not only is SNCA deposition clearly distinguishable between MSA and PD cases but MSA-like pathology underlies both cerebellar (MSA-C) and parkinsonian (MSA-P) manifestations. There is also minimal change MSA pathology in some cases that have a longer disease duration. How this single protein can apparently be the culprit in these different disease phenotypes, with such varied localization in different cell types and brain regions, is an unresolved question.

One compelling explanation for the clinicopathological diversity in the synucleinopathies is that distinct strains of SNCA are responsible for generating heterogeneity ${ }^{20}$. These conformational variants include different oligomer combinations, fibrils and ribbons, although their relative contribution to the anatomical distribution and deposition of SNCA in MSA and other synucleinopathies and the formation of GCIs in MSA has yet to be determined. Furthermore, it has been posited that the specific structure of SNCA derived from inclusions in the brains of patients with MSA is especially toxic, capable of propagating to adjacent cells and inducing neurodegeneration when injected into transgenic mice, akin to the permissive templating of prion protein and even prompting reclassification of MS A as a prion disease $^{21,22}$. However, it remains to be shown conclusively that oligodendroglial MSA-type pathology is provoked by seeded aggregation of SNCA.

The pathomechanisms of MSA are being steadily elucidated as studies examine the molecular interactions of SNCA with other proteins in MSA. A recent study ${ }^{23}$ has reported that SNCA engages with proteins that regulate autophagy in the MSA brain, implicating cellular degradation as central to the pathogenesis of MSA and potentially unifying it with other neurodegenerative diseases for the purpose of therapeutic intervention of these pathways ${ }^{23,24}$. Additionally, there is an emerging conviction that SNCA induces deficits in myelination ${ }^{25}$ and there is a possible role for inflammatory/apoptotic mechanisms.

Mutations and copy number variation in $\alpha$-synuclein The initial genome-wide association study (GWAS) in PD yielded significant association at the SNCA and microtubule-associated protein tau $(M A P T)$ genes ${ }^{26}$. Common variation in the gene encoding SNCA was first identified as a risk factor for MSA in $2009^{27}$, but the association of variants across SNCA in different populations was not replicated in later studies ${ }^{28-32}$ and was thought to be due to a mixed control population used in the initial studies. The first GWAS to be conducted in MSA yielded negative results around the SNCA locus ${ }^{28}$. As mentioned earlier, several SNCA point mutations ${ }^{14,33-39}$ and SNCA gene duplications ${ }^{40}$, triplications $s^{41,42}$, and double duplications ${ }^{43}$ have been associated with familial forms of PD (Figure 1 and Table 1 and Table 2). Some of these families have manifestations of both PD and MSA and have clinical signs or neuropathological features or both ${ }^{44,45}$. In particular, the A53T, A53E, and G51D mutations and SNCA gene triplications are associated with a more aggressive MSA-like clinical and pathological phenotype ${ }^{45}$ (See Table 1 and Table 2 for details of the clinical and neuropathological features of SNCA mutations). Exactly why the codon 51 and 53 mutations in the SNCA gene lead to an MSA-like clinical and pathological phenotype is not known, but this is likely to be associated with the importance of this defined region and toxic gain of function of these protein changes (Figure 1) ${ }^{46}$. 


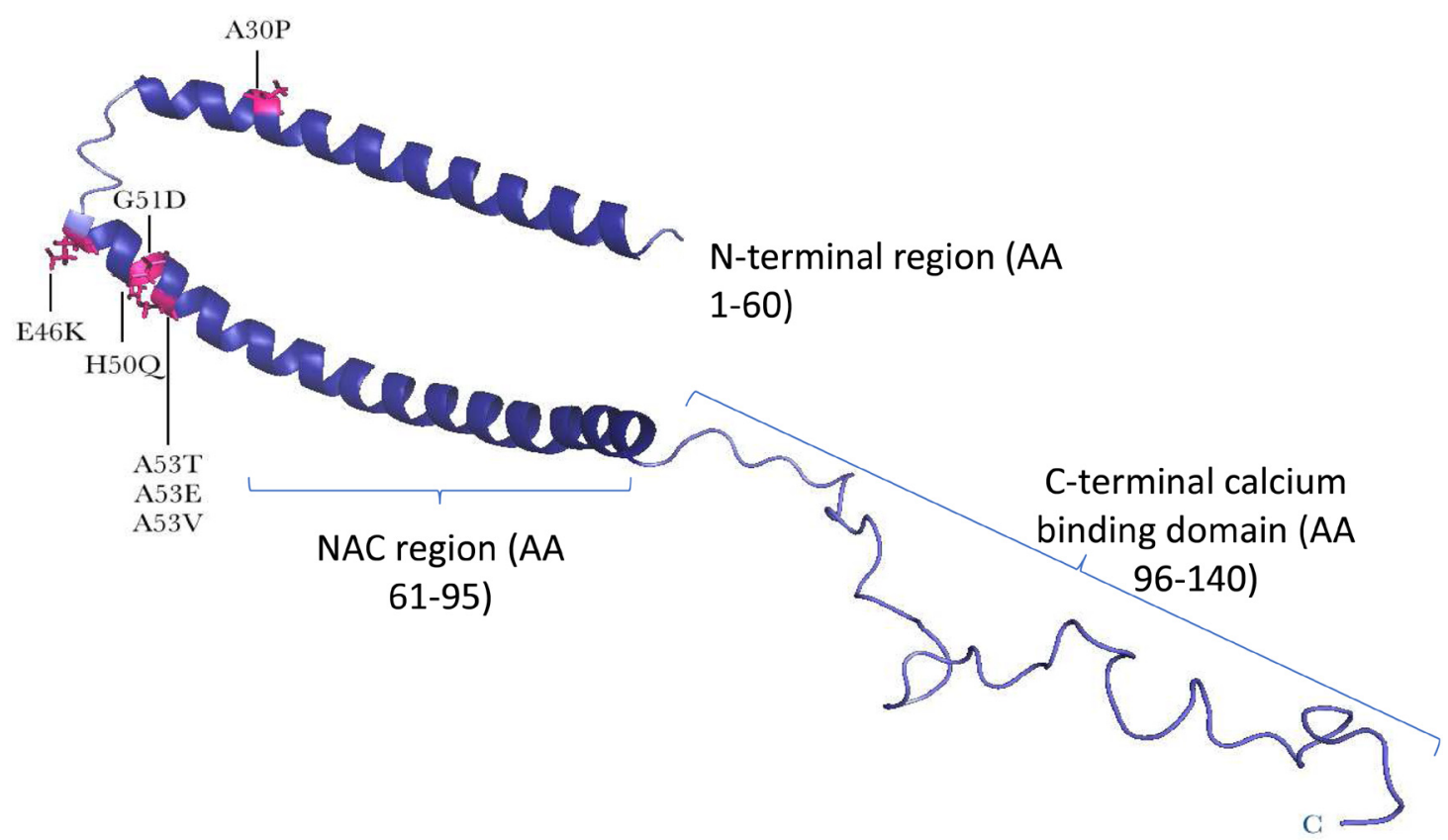

Figure 1. Structural features of the alpha-synuclein monomer. A structure of the full-length, membrane-bound form of alpha-synuclein (SNCA) protein reveals a conformation in which the N-terminal two-thirds of the protein forms a broken, amphipathic alpha-helix. This structured portion of the protein is responsible for membrane binding, and residues at the very N-terminus are essential for this process. In the nuclear magnetic resonance structure of SNCA, the negatively charged C-terminal tail remains flexible and disordered (based on Yu et al. ${ }^{46}$ ). The positions of point mutations associated with Parkinson's disease are indicated with arrows and in pink. All mutations are heterozygous, except for p.A53V, which is homozygous.

From a clinical perspective, if there is any hint of a family history in patients with MSA, then the SNCA gene should be sequenced by using traditional Sanger ${ }^{47}$, gene panel, or exome sequencing and analysed for copy number changes ${ }^{48}$.

\section{Other genetic risk factors for multiple system atrophy}

A number of PD risk factors have not been replicated in MSA $^{4,6,48-61}$, but other disorders such as spinocerebellar ataxia type 17 and progressive supranuclear palsy ${ }^{62-64}$ can mimic MSA in the early stages and should be included in clinical and genetic testing. In a statistical analysis of 5,302 patients with PD and 4,161 controls from 15 sites, Elbaz and colleagues found no evidence for an interactive effect between the $\mathrm{H} 1$ haplotype in the $M A P T$ gene and single-nucleotide polymorphisms in the SNCA gene on disease ${ }^{65}$. Variation in each gene was associated with PD risk, indicating independent effects. In MSA, the H1 haplotype has been associated with $\mathrm{MSA}^{66}$ and the MAPT gene was also implicated in the MSA GWAS ${ }^{28}$. Familial inheritance of MSA is rare but has been observed. These families often have atypical clinical features, and the genetic analysis led to the discovery of mutations in the $\mathrm{COQ}_{2}$ gene, which plays a role in synthesising the mitochondrial electron transporter and antioxidant coenzyme $\mathrm{Q}_{10}$. These mutations were posited to impair the activity of the mitochondrial respiratory chain and increase oxidative stress, implicating $\mathrm{COQ}_{2}$ variants as a risk factor for sporadic $\mathrm{MSA}^{58}$.
Though initially promising, these findings have not been consistently replicated in various populations, refuting $\mathrm{COQ}_{2}$ polymorphisms as common MSA risk factors ${ }^{58}$. Nonetheless, this has turned attention, and emerging hypotheses centre on mitochondrial dysfunction as a central component of the pathophysiological cascade in MSA ${ }^{67}$.

The first GWAS in MSA was carried out by Sailer and colleagues and was extremely important but challenging given the rarity of $\mathrm{MSA}^{28}$. At just under 1,000 MSA cases, the analysis was still statistically under-powered ${ }^{28}$. Studies that are more highly powered are needed to follow up on the importance of the three genes identified that were flagged for being associated: FBXO47, ELOVL7, and $M A P T^{28}$. It will be important to follow this GWAS up with greater numbers of MSA cases, analyse age at onset association ${ }^{68-70}$, and employ advanced transcriptome sequencing in MSA patient brain tissue to assess the associated genes and other genes thought to be involved in MSA, such as immune-responsive and iron metabolism genes ${ }^{71,72}$.

\section{Clinical genetic testing and translation}

Accurate and early diagnosis of MSA continues to be an important research objective as the heterogeneous features of PD and other atypical parkinsonism syndromes can mimic MSA. One retrospective clinicopathological study revealed that $38 \%$ of patients were misdiagnosed with MSA on the basis of expert interpretation 


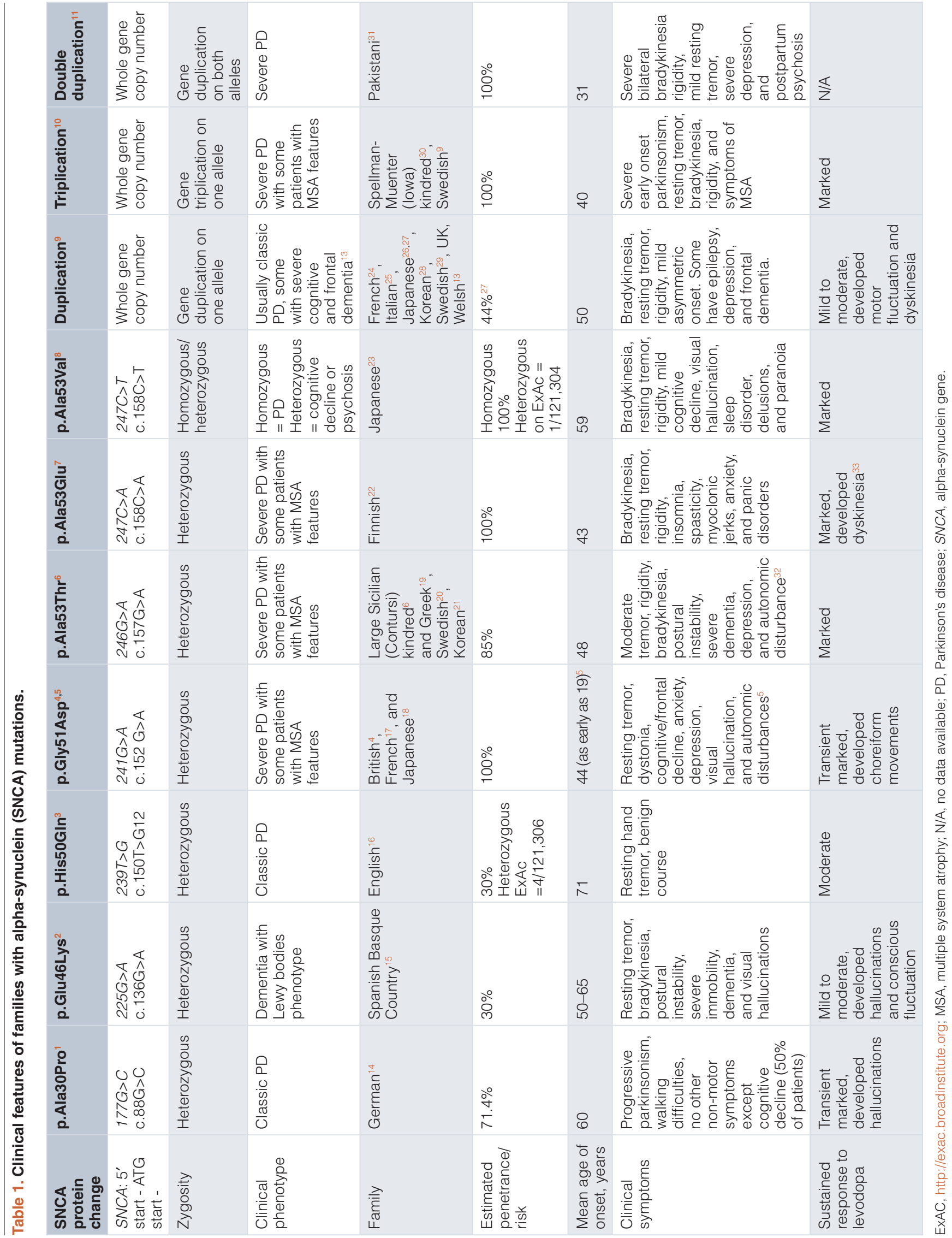




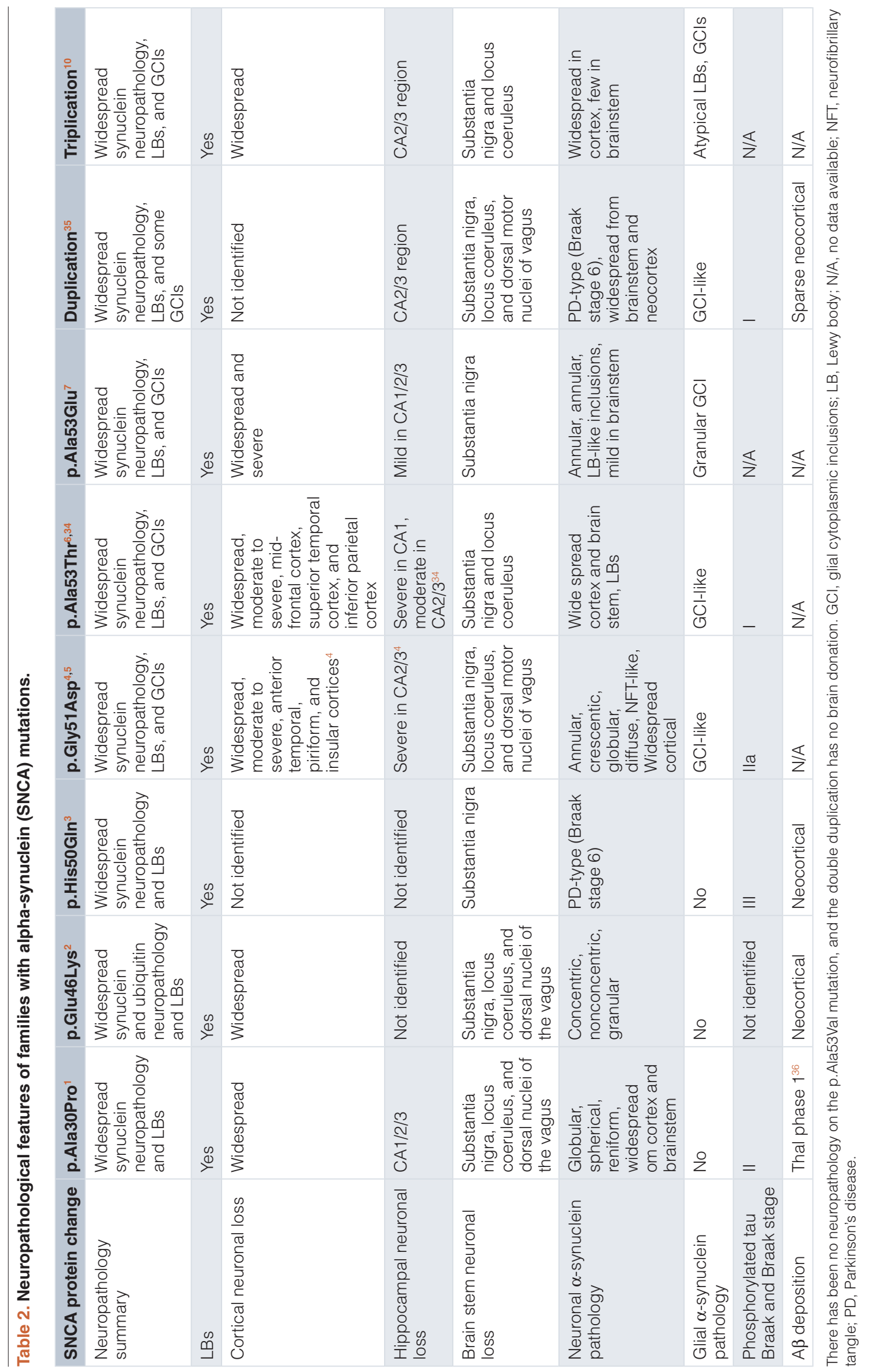


of their symptomatic presentation ${ }^{73-75}$. Genetic analysis will be important to identify the rare MSA cases with SNCA mutations and to help differentiate MSA from similar disorders such as spinocerebellar ataxia type $17^{62,64}$. Thus, biomarkers that are more sensitive are imperative to improve diagnosis and enlist individuals with the appropriate disease in clinical trials. This will be imperative in the development of effective treatments for the MSA patient population. Both $\alpha$-synuclein and $\mathrm{CoQ}_{10}$ are being pursued as potential therapeutic targets, and international collaborative study groups are promoting this work with $\mathrm{CoQ}_{10}$ supplementation, the preparation of $\alpha$-synuclein antisense oligonucleotide, and immunisation trials to be conducted in PD and MSA patients by either intravenous or intrathecal routes.

Until disease-modifying treatments become available, symptom management will remain the mainstay of care for patients with MSA. Patient support organisations such as the MSA Trust (www. msatrust.org.uk/) and the MSA coalition (https://www.multiplesystematrophy.org/) and their clinical nurse specialists are essential in providing support and advice on patient care in this rare disorder. The established drugs for controlling parkinsonism, such as L-dopa, can be effective in the early stages of MSA but often worsen the symptoms due to hypotension later in the disease. A rational treatment, based on the pathophysiology of MSA and perhaps repurposed from $\mathrm{PD}$ trials, needs to be developed to offer patients with MSA hope for this devastating disorder.

\section{Competing interests}

The authors declare that they have no competing interests.

\section{Grant information}

We are grateful to the MSA Trust, the MSA Coalition, the Medical Research Council (MRC UK), the Wellcome Trustequipment and the Synaptopathies Strategic Award (104033) and the EU FP7/2007-2013 under grant agreement 2012-305121 (NEUROMICS), the MDA USA, Muscular Dystrophy UK, the Rosetrees Trust, Ataxia UK, and the Brain Research Trust. We are also supported by the National Institute for Health Research (NIHR) University College London Hospitals (UCLH) Biomedical Research Centre.

The funders had no role in study design, data collection and analysis, decision to publish, or preparation of the manuscript.

\section{Acknowledgements}

The authors would like to thank the patients and their families for their essential help with this work.
1. Schrag A, Ben-Shlomo Y, Quinn NP: Prevalence of progressive supranuclear palsy and multiple system atrophy: a cross-sectional study. Lancet. 1999; 354(9192): 1771-5

PubMed Abstract | Publisher Full Text

2. Tison F, Yekhlef F, Chrysostome V, et al:: Prevalence of multiple system atrophy. Lancet. 2000; 355(9202): 495-6.

PubMed Abstract | Publisher Full Text

3. Ahmed Z, Asi YT, Sailer A, et al:: The neuropathology, pathophysiology and genetics of multiple system atrophy. Neuropathol Appl Neurobiol. 2012; 38(1): $4-24$.

PubMed Abstract | Publisher Full Text

4. Federoff M, Schottlaender LV, Houlden $\mathrm{H}$, et al:: Multiple system atrophy: the application of genetics in understanding etiology. Clin Auton Res. 2015; 25(1): 19-36.

PubMed Abstract | Publisher Full Text | Free Full Text

5. Federoff M, Price TR, Sailer A, et al:: Genome-wide estimate of the heritability of Multiple System Atrophy. Parkinsonism Relat Disord. 2016; 22: 35-41. PubMed Abstract | Publisher Full Text | Free Full Text

6. Kara E, Xiromerisiou G, Spanaki C, et al: Assessment of Parkinson's disease risk loci in Greece. Neurobiol Aging. 2014; 35(2): 442.e9-442.e16. PubMed Abstract | Publisher Full Text | Free Full Text

7. Lantos PL, Papp MI: Cellular pathology of multiple system atrophy: a review. J Neurol Neurosurg Psychiatr. 1994; 57(2): 129-33.

PubMed Abstract | Publisher Full Text | Free Full Text

8. Mezey E, Dehejia A, Harta G, et al.: Alpha synuclein in neurodegenerative disorders: murderer or accomplice? Nat Med. 1998; 4(7): 755-7. PubMed Abstract | Publisher Full Text

9. Papp MI, Kahn JE, Lantos PL: Glial cytoplasmic inclusions in the CNS of patients with multiple system atrophy (striatonigral degeneration, olivopontocerebellar atrophy and Shy-Drager syndrome). J Neurol Sci. 1989 94(1-3): 79-100.

PubMed Abstract | Publisher Full Text

10. Papp MI, Lantos PL: Accumulation of tubular structures in oligodendroglial and neuronal cells as the basic alteration in multiple system atrophy. $J$ Neurol Sci. 1992; 107(2): 172-82.

PubMed Abstract | Publisher Full Text

11. Papp MI, Lantos PL: The distribution of oligodendroglial inclusions in multiple system atrophy and its relevance to clinical symptomatology. Brain. 1994; 117(Pt 2): 235-43.

PubMed Abstract | Publisher Full Text

12. Spillantini MG, Goedert M: The alpha-synucleinopathies: Parkinson's disease, dementia with Lewy bodies, and multiple system atrophy. Ann NY Acad Sci. 2000; 920: 16-27.

PubMed Abstract | Publisher Full Text

13. Polymeropoulos MH: Genetics of Parkinson's disease. Ann NY Acad Sci. 2000; 920: 28-32.

PubMed Abstract | Publisher Full Text

14. Polymeropoulos $\mathrm{MH}$, Lavedan $\mathrm{C}$, Leroy $\mathrm{E}$, et al:: Mutation in the alpha-synuclein gene identified in families with Parkinson's disease. Science. 1997; 276(5321): 2045-7.

PubMed Abstract | Publisher Full Text

15. Kara E, Kiely AP, Proukakis C, et al: A 6.4 Mb duplication of the $\alpha$-synuclein locus causing frontotemporal dementia and Parkinsonism: phenotypegenotype correlations. JAMA Neurol. 2014; 71(9): 1162-71. PubMed Abstract | Publisher Full Text | Free Full Text

16. $\mathrm{F}$ Logan $\mathrm{T}$, Bendor J, Toupin C, et al:: $\boldsymbol{\alpha}$-Synuclein promotes dilation of the exocytotic fusion pore. Nat Neurosci. 2017; 20(5): 681-9. PubMed Abstract | Publisher Full Text | Free Full Text | F1000 Recommendation

17. Bendor JT, Logan TP, Edwards RH: The function of $\alpha$-synuclein. Neuron. 2013; 79(6): 1044-66.

PubMed Abstract | Publisher Full Text | Free Full Text

18. F Doppler K, Weis J, Karl K, et al.: Distinctive distribution of phospho-alphasynuclein in dermal nerves in multiple system atrophy. Mov Disord. 2015; 30(12): 1688-92.

PubMed Abstract | Publisher Full Text | F1000 Recommendation

19. F Zange L, Noack C, Hahn K, et al:: Phosphorylated $\alpha$-synuclein in skin nerve fibres differentiates Parkinson's disease from multiple system atrophy. Brain. 2015; 138(Pt 8): 2310-21. PubMed Abstract | Publisher Full Text | F1000 Recommendation

20. F Peelaerts W, Bousset L, van der Perren A, et al:: $\alpha$-Synuclein strains cause distinct synucleinopathies after local and systemic administration. Nature. 2015; 522(7556): 340-4.

PubMled Abstract | Publisher Full Text | F1000 Recommendation 
21. F Prusiner SB, Woerman AL, Mordes DA, et al.: Evidence for $\boldsymbol{\alpha}$-synuclein prions causing multiple system atrophy in humans with parkinsonism. Proc Natl Acad Sci U S A. 2015; 112(38): E5308-17. PubMed Abstract | Publisher Full Text | Free Full Text | F1000 Recommendation

22. F Woerman AL, Watts JC, Aoyagi A, et al:: $\alpha$-Synuclein: Multiple System Atrophy Prions. Cold Spring Harb Perspect Med. 2017; pii: a024588. PubMed Abstract | Publisher Full Text | Free Full Text | F1000 Recommendation

23. $\mathrm{F}$ Miki $\mathrm{Y}$, Tanji $\mathrm{K}$, Mori $\mathrm{F}$, et al:: AMBRA1, a novel $\boldsymbol{\alpha}$-synuclein-binding protein, is implicated in the pathogenesis of multiple system atrophy. Brain Pathol. 2016.

PubMed Abstract | Publisher Full Text | F1000 Recommendation

24. Ghiso JA, Holton J, Miravalle L, et al:: Systemic amyloid deposits in familial British dementia. J Biol Chem. 2001; 276(47): 43909-14. PubMed Abstract | Publisher Full Text

25. F Ettle B, Kerman BE, Valera E, et al:: $\boldsymbol{\alpha}$-Synuclein-induced myelination deficit defines a novel interventional target for multiple system atrophy. Acta Neuropathol. 2016; 132(1): 59-75.

PubMed Abstract | Publisher Full Text | Free Full Text | F1000 Recommendation

26. F Simón-Sánchez J, Schulte C, Bras JM, et al: Genome-wide association study reveals genetic risk underlying Parkinson's disease. Nat Genet. 2009; 41(12): 1308-12.

PubMed Abstract | Publisher Full Text | Free Full Text | F1000 Recommendation

27. Scholz SW, Houlden $\mathrm{H}$, Schulte $\mathrm{C}$, et al: SNCA variants are associated with increased risk for multiple system atrophy. Ann Neurol. 2009; 65(5): 610-4. PubMed Abstract | Publisher Full Text | Free Full Text

28. Sailer A, Scholz SW, Nalls MA, et al:: A genome-wide association study in multiple system atrophy. Neurology. 2016; 87(15): 1591-8. PubMed Abstract | Publisher Full Text | Free Full Text

29. Conedera S, Apaydin H, Li Y, et al.: FBXO7 mutations in Parkinson's disease and multiple system atrophy. Neurobiol Aging. 2016; 40: 192.e1-5. PubMed Abstract | Publisher Full Tex

30. Chen Y, Wei Q, Ou R, et al:: Genetic Variants of SNCA Are Associated with Susceptibility to Parkinson's Disease but Not Amyotrophic Lateral Sclerosis or Multiple System Atrophy in a Chinese Population. PLoS One. 2015; 10(7): e0133776.

PubMed Abstract | Publisher Full Text | Free Full Text

31. Sun Z, Xiang X, Tang B, et al:: SNP rs11931074 of the SNCA gene may not be associated with multiple system atrophy in Chinese population. Int $J$ NeurosCi 2015; 125(8): 612-5.

PubMed Abstract | Publisher Full Text

32. Al-Chalabi A, Dürr A, Wood NW, et al:: Genetic variants of the alpha-synuclein gene SNCA are associated with multiple system atrophy. PLoS One. 2009; 4(9): e7114.

PubMed Abstract | Publisher Full Text | Free Full Text

33. Krüger R, Kuhn W, Müller T, et al:: Ala30Pro mutation in the gene encoding alpha-synuclein in Parkinson's disease. Nat Genet. 1998; 18(2): 106-8. PubMed Abstract | Publisher Full Text

34. Proukakis C, Dudzik CG, Brier T, et al:: A novel $\alpha$-synuclein missense mutation in Parkinson disease. Neurology. 2013; 80(11): 1062-4. PubMed Abstract | Publisher Full Text | Free Full Text

35. Kiely AP, Asi YT, Kara E, et al:: $\alpha$-Synucleinopathy associated with G51D SNCA mutation: a link between Parkinson's disease and multiple system atrophy? Acta Neuropathol. 2013; 125(5): 753-69. PubMed Abstract | Publisher Full Text | Free Full Text

36. F Zarranz JJ, Alegre J, Gómez-Esteban JC, et al.: The new mutation, E46K, of alpha-synuclein causes Parkinson and Lewy body dementia. Ann Neurol. 2004 55(2): 164-73

PubMed Abstract | Publisher Full Text | F1000 Recommendation

37. Lesage S, Anheim M, Letournel F, et al:: G51D $\alpha$-synuclein mutation causes a novel parkinsonian-pyramidal syndrome. Ann Neurol. 2013; 73(4): 459-71. PubMed Abstract | Publisher Full Text

38. Pasanen $\mathrm{P}$, Myllykangas $\mathrm{L}$, Siitonen $\mathrm{M}$, et al:: Novel $\alpha$-synuclein mutation A53E associated with atypical multiple system atrophy and Parkinson's diseasetype pathology. Neurobiol Aging. 2014; 35(9): 2180.e1-5. PubMed Abstract | Publisher Full Text

39. $\mathrm{F}$ Yoshino $\mathrm{H}$, Hirano $\mathrm{M}$, Stoessl $\mathrm{AJ}$, et al:: Homozygous alpha-synuclein p.A53V in familial Parkinson's disease. Neurobiol Aging. 2017; 57: 248.e7-248.e12. PubMed Abstract | Publisher Full Text | F1000 Recommendation

40. Ibáñez $\mathrm{P}$, Bonnet AM, Débarges $\mathrm{B}$, et al: Causal relation between alphasynuclein gene duplication and familial Parkinson's disease. Lancet. 2004; 364(9440): 1169-71.

PubMed Abstract | Publisher Full Text

41. Johnson J, Hague SM, Hanson M, et al:: SNCA multiplication is not a common cause of Parkinson disease or dementia with Lewy bodies. Neurology. 2004; 63(3): 554-6.

PubMed Abstract | Publisher Full Tex

42. $\mathrm{F}$ Singleton $\mathrm{AB}$, Farrer $\mathrm{M}$, Johnson J, et al:: alpha-Synuclein locus triplication causes Parkinson's disease. Science. 2003; 302(5646): 841 PubMed Abstract | Publisher Full Text | F1000 Recommendation

43. Kojovic M, Sheerin UM, Rubio-Agusti I, et al.: Young-onset parkinsonism due to homozygous duplication of $\alpha$-synuclein in a consanguineous family. Mov Disord. 2012; 27(14): 1827-9.

PubMed Abstract | Publisher Full Text

44. F Fanciulli A, Wenning GK: Multiple-system atrophy. N Engl J Med. 2015 372(3): 249-63.

PubMed Abstract | Publisher Full Text | F1000 Recommendation

45. Kiely AP, Ling H, Asi YT, et al.: Distinct clinical and neuropathological features of G51D SNCA mutation cases compared with SNCA duplication and H50Q mutation. Mol Neurodegener. 2015; 10: 41.

PubMed Abstract | Publisher Full Text | Free Full Text

46. $\mathrm{F}$ Yu H, Han W, Ma W, et al.: Transient $\beta$-hairpin formation in $\alpha$-synuclein monomer revealed by coarse-grained molecular dynamics simulation. $J$ Chem Phys. 2015; 143(24): 243142.

PubMed Abstract | Publisher Full Text | Free Full Text | F1000 Recommendation

47. Houlden H, King RH, Hashemi-Nejad A, et al:: A novel TRK A (NTRK1) mutation associated with hereditary sensory and autonomic neuropathy type V. Ann Neurol. 2001; 49(4): 521-5

PubMed Abstract | Publisher Full Text

48. Singleton $\mathrm{AB}$, Hardy J, Traynor BJ, et al.: Towards a complete resolution of the genetic architecture of disease. Trends Genet. 2010; 26(10): 438-42. PubMed Abstract | Publisher Full Text | Free Full Text

49. Paisán-Ruiz C, Guevara R, Federoff M, et al.: Early-onset L-dopa-responsive parkinsonism with pyramidal signs due to ATP13A2, PLA2G6, FBXO7 and spatacsin mutations. Mov Disord. 2010; 25(12): 1791-800.

PubMed Abstract | Publisher Full Text

50. Tucci A, Nalls MA, Houlden H, et al.: Genetic variability at the PARK16 locus. Eur J Hum Genet. 2010; 18(12): 1356-9.

PubMed Abstract | Publisher Full Text | Free Full Text

51. Brooks JA, Houlden $\mathrm{H}$, Melchers A, et al:: Mutational analysis of parkin and PINK1 in multiple system atrophy. Neurobiol Aging. 2011; 32(3): 548.e5-7. PubMed Abstract | Publisher Full Text | Free Full Text

52. Houlden $\mathrm{H}$, Singleton $\mathrm{AB}$ : The genetics and neuropathology of Parkinson's disease. Acta Neuropathol. 2012; 124(3): 325-38. PubMed Abstract | Publisher Full Text | Free Full Text

53. Kara E, Ling H, Pittman AM, et al.: The MAPT p.A152T variant is a risk factor associated with tauopathies with atypical clinical and neuropathological features. Neurobiol Aging. 2012; 33(9): 2231.e7-2231.e14. PubMed Abstract | Publisher Full Text | Free Full Text

54. Paudel R, Hardy J, Revesz T, et al.: Review: genetics and neuropathology of primary pure dystonia. Neuropathol Appl Neurobiol. 2012; 38(6): 520-34. PubMed Abstract | Publisher Full Text

55. Duran R, Mencacci NE, Angeli AV, et al.: The glucocerobrosidase E326K variant predisposes to Parkinson's disease, but does not cause Gaucher's disease. Mov Disord. 2013; 28(2): 232-6.

PubMed Abstract | Publisher Full Text | Free Full Text

56. Kara E, Hardy J, Houlden $\mathrm{H}$ : The pallidopyramidal syndromes: nosology, aetiology and pathogenesis. Curr Opin Neurol. 2013; 26(4): 381-94. PubMed Abstract | Publisher Full Text | Free Full Text

57. Proukakis $\mathrm{C}$, Houlden $\mathrm{H}$, Schapira $\mathrm{AH}$ : Somatic alpha-synuclein mutations in Parkinson's disease: hypothesis and preliminary data. Mov Disord. 2013; 28(6): 705-12.

PubMed Abstract | Publisher Full Text | Free Full Text

58. Schottlaender LV, Houlden H, Multiple-System Atrophy (MSA) Brain Bank Collaboration: Mutant COQ2 in multiple-system atrophy. N Engl J Med. 2014 371(1): 81 .

PubMed Abstract | Publisher Full Text

59. Schottlaender LV, Polke JM, Ling H, et al.: Analysis of C9orf72 repeat expansions in a large series of clinically and pathologically diagnosed cases with atypical parkinsonism. Neurobiol Aging. 2015; 36(2): 1221.e1-6. PubMed Abstract | Publisher Full Text | Free Full Text

60. Segarane B, Li A, Paudel R, et al.: Glucocerebrosidase mutations in 108 neuropathologically confirmed cases of multiple system atrophy. Neurology. 2009; 72(13): 1185-6.

PubMed Abstract | Publisher Full Text | Free Full Text

61. Scholz SW, Majounie E, Revesz T, et al:: Multiple system atrophy is not caused by C9orf72 hexanucleotide repeat expansions. Neurobiol Aging. 2015; 36(2): 1223.e1-2.

PubMed Abstract | Publisher Full Text | Free Full Text

62. Kim HJ, Jeon BS, Shin J, et al:: Should genetic testing for SCAs be included in the diagnostic workup for MSA? Neurology. 2014; 83(19): 1733-8. PubMed Abstract | Publisher Full Text

63. Kim JY, Kim SY, Kim JM, et al.: Spinocerebellar ataxia type 17 mutation as a causative and susceptibility gene in parkinsonism. Neurology. 2009; 72(16) 1385-9.

PubMed Abstract | Publisher Full Text

64. Lin IS, Wu RM, Lee-Chen GJ, et al:: The SCA17 phenotype can include features of MSA-C, PSP and cognitive impairment. Parkinsonism Relat Disord. 2007; 13(4): 246-9.

PubMed Abstract | Publisher Full Text

65. Elbaz A, Ross OA, loannidis JP, et al:: Independent and joint effects of the MAPT and SNCA genes in Parkinson disease. Ann Neurol. 2011; 69(5): 778-92. PubMed Abstract | Publisher Full Text | Free Full Text 
66. F Labbé C, Heckman MG, Lorenzo-Betancor O, et al:: MAPT haplotype diversity in multiple system atrophy. Parkinsonism Relat Disord. 2016; 30: 40-5.

PubMed Abstract | Publisher Full Text | Free Full Text | F1000 Recommendation

67. Schottlaender LV, Bettencourt C, Kiely AP, et al:: Coenzyme Q10 Levels Are Decreased in the Cerebellum of Multiple-System Atrophy Patients. PLOS One. 2016; 11(2): e0149557.

2016; 11(2): e0149557.

68. Houlden H, Baker M, Adamson J, et al:: Frequency of tau mutations in three series of non-Alzheimer's degenerative dementia. Ann Neurol. 1999; 46(2): 243-8.

PubMed Abstract | Publisher Full Text

69. Houlden H, Rizzu P, Stevens M, et al:: Apolipoprotein E genotype does not affect the age of onset of dementia in families with defined tau mutations. Neurosci Lett. 1999; 260(3): 193-5.
PubMed Abstract | Publisher Full Text

70. Talbot $\mathrm{C}$, Houlden $\mathrm{H}$, Craddock $\mathrm{N}$, et al:: Polymorphism in AACT gene may lower age of onset of Alzheimer's disease. Neuroreport. 1996; 7(2): 534-6.

PubMed Abstract | Publisher Full Text
71. Chen BJ, Mills JD, Takenaka K, et al:: Characterization of circular RNAs landscape in multiple system atrophy brain. J Neurochem. 2016; 139(3): 485-96. PubMed Abstract | Publisher Full Text

72. Mills JD, Ward M, Kim WS, et al.: Strand-specific RNA-sequencing analysis of multiple system atrophy brain transcriptome. Neuroscience. 2016; 322: 234-50. PubMed Abstract | Publisher Full Text

73. F Koga S, Aoki N, Uitti RJ, et al:: When DLB, PD, and PSP masquerade as MSA: an autopsy study of 134 patients. Neurology. 2015; 85(5): 404-12. PubMed Abstract | Publisher Full Text | Free Full Text | F1000 Recommendation

74. F Aoki N, Boyer PJ, Lund C, et al:: Atypical multiple system atrophy is a new subtype of frontotemporal lobar degeneration: frontotemporal lobar degeneration associated with $\alpha$-synuclein. Acta Neuropathol. 2015; 130(1): 93-105.

PubMed Abstract | Publisher Full Text | F1000 Recommendation

75. Joutsa J, Gardberg M, Röyttä M, et al.: Diagnostic accuracy of parkinsonism syndromes by general neurologists. Parkinsonism Relat Disord. 2014; 20(8): 840-4 PubMed Abstract | Publisher Full Text 


\section{Open Peer Review}

\section{Current Peer Review Status:}

\section{Editorial Note on the Review Process}

Faculty Reviews are review articles written by the prestigious Members of Faculty Opinions. The articles are commissioned and peer reviewed before publication to ensure that the final, published version is comprehensive and accessible. The reviewers who approved the final version are listed with their names and affiliations.

\section{The reviewers who approved this article are:}

\section{Version 1}

\section{Dean Pountney}

School of Medical Science, Griffith University, Queensland, Australia

Competing Interests: No competing interests were disclosed.

\section{Mathias Toft}

Department of Neurology, Oslo University Hospital, Oslo, Norway

Competing Interests: No competing interests were disclosed.

The benefits of publishing with F1000Research:

- Your article is published within days, with no editorial bias

- You can publish traditional articles, null/negative results, case reports, data notes and more

- The peer review process is transparent and collaborative

- Your article is indexed in PubMed after passing peer review

- Dedicated customer support at every stage

For pre-submission enquiries, contact research@f1000.com 